\begin{tabular}{|c|c|c|}
\hline$A$ & $\begin{array}{c}\text { International Journal of Current Research } \\
\text { and Academic Review }\end{array}$ & vatede \\
\hline $\begin{array}{l}\text { EXCELLENT } \\
\text { PUBLISHERS }\end{array}$ & $\begin{array}{c}\text { ISSN: 2347-3215 (Online) Volume } 6 \text { Number } 10 \text { (October-2018) } \\
\text { Journal homepage: http://www.ijcrar.com }\end{array}$ & \\
\hline
\end{tabular}

doi: https://doi.org/10.20546/ijcrar.2018.610.006

\title{
Bacteriological and Physicochemical Quality of Swimming Pools in Bahir Dar, Ethiopia
}

\author{
Melkam Dessalegn* and Mulugeta Kibret
}

Bahir Dar, Ethiopia

*Corresponding author

\begin{abstract}
Swimming pool is a water body that has been created artificially for swimming. It has been used to do for different activities like recreational activity, sport and rehabilitative treatment. In spite of its importance to human, it has been recognized as disease transmission channel in the world. In Ethiopia, there is a scarcity of information on the microbial load of swimming pools. So, a cross-sectional study was carried out from December to February, 2012 to 2013 to assess the bacteriological and physicochemical quality of swimming pools in Bahir Dar, Ethiopia. A total of 81 water samples from three swimming pools were collected and used for examination of total coliforms, fecal coliforms, heterotrophic bacteria, temperature, $\mathrm{pH}$, residual chlorine and turbidity. From total of 81 pool water samples, $72 \%$ and $74 \%$ were unacceptable to WHO standard of bacteriological and physicochemical limits respectively. For total coliforms 68 (84\%), for heterotrophic plate count $65(80 \%)$, for faecal coliform $61(75 \%)$, for turbidity 64 (79\%), for $\mathrm{pH} 61(75 \%)$ and temperature $63(78 \%)$ were above WHO standard. Residual chlorine of all pool water samples $(100 \%)$ was less than WHO standard. The result indicates that there was poor pool water treatment because majority of pool water samples were not fulfilled WHO standard. So, there is needed to implement pool safety guideline measures by responsible health authority for protection of swimmers' health.
\end{abstract}

\section{Article Info}

Accepted: 04 September 2018

Available Online: 20 October 2018

\section{Keywords}

Pool water, coliforms, $\mathrm{pH}$, residual chlorine, swimming pool illness

\section{Introduction}

A swimming pool is a concrete tank or an artificial basin filled with water intended for swimming. It can be found in different kinds and sizes in public areas, hotels or private homes (Thomas and Trammel, 2007). People from developed and developing countries enjoy around or nearby of water bodies such as swimming pools. In worldwide, large numbers of people are taking up swimming activities because its benefits like leisure, mental and physical health importance, decrease chronic illnesses and improve the health of people with diabetes and heart disease (Chase, 2008). Swimming is recognized as one of the most beneficial form of sport, recreational activity and rehabilitative treatment (WHO, 2006).

In spite of importance and popularity of swimming pool, it has been identified as causing swimming pool water illness (SPWIs). SPWIs are illnesses that are spread by swallowing, breathing or having contact with contaminated water and environment of pool. Use of swimming pool can cause a wide variety of SPWI symptoms including gastroenteritis, cholera, paratyphoid 
fever, typhoid fever, diarrhea, cryptosporidiosis, giardiasis, dysentery, mycoses, hypersensitivity pneumonitis, hepatitis and pharyngitis) (CDC, 2008). SPWIs may have serious and life-threatening consequences, particularly in high-risk population groups such as the immunosuppressed people, pregnant women, the elderly and the young people. Infections with $E$. coli O157:H7 may have disastrous consequences in the pediatric and elderly population when hemolytic uremic syndrome develops as a sequela. Another example is the significant morbidity associated with Cryptosporidium infections in the immunosuppressed population (Castor, 2004).

It is globally accepted that a wide variety of microorganisms can be present in water and environment of pools which contribute to various types of infections. Water and environment of pools can be contaminated by infected users and then play important role in infecting the healthy users. Infected users can introduce different type of pathogens into pool water through their feces, vomit, mucus, saliva or skin (Nabizadeh et al., 2008).

Swimmers' feces are the most source of pool water contamination with pathogens which have been linked to cause the majority of SPWIs (Bello et al., 2012). Feces are reached to pool water either released accidentally by swimmers or washed away from swimmers' bodies (CDC, 2001). There have been many reported cases of infectious diseases caused by the accidental swallowing of pool water contaminated with pathogens (Rasti et al., 2012). Pathogens like Cryptosporidium, Giardia, Campylobacter, Escherichia, Salmonella and Shigella are transmitted from swimmers into pool water through their feces and then transmitted from pool water to its users through unintentional swallowing of pool water while swimming (Bello et al., 2012).

Swimming pool water is a dynamic environment that changes with the climate, the number and behavior of people in the pool, activities of the swimmers as well as environmental contaminants. It is also accommodating a wide range of people like children, pregnant women, the elderly, people with immune compromised and Olympic athletes. All these conditions make the swimming pool as a challenging environment in which to achieve a suitable public health outcome (Thomas, 2007). Poor pool maintenance, the emergence of chlorine-resistant germs and pool staff illnesses are also make a challenge for reducing pool related health risks and increase the complexity of any plan to prevent the spread of SPWIs in swimming pools (CDC, 2008).
Swimming pools are well-documented transmission vehicle for infectious diseases throughout the world. But in Ethiopia, swimming pool safety issues are not well understood and have received little attention. There was also no study done concerning bacteriological and physico-chemical quality of swimming pools found in Ethiopia specifically in Bahir Dar. So, the current study was designed to assess the bacteriological and physicochemical quality of swimming pools in Bahir Dar in order to inform the current status of pool safety for concerned body who controls swimming pool health related problems.

\section{Materials and Methods}

\section{Study area}

The study was conducted in Bahir Dar which is the capital city of Amhara region. It is found on the southern shore of Lake Tana, the source of the Blue Nile. It is located $578 \mathrm{~km}$ far away from Addis Ababa, the capital city of Ethiopia. It has altitude and longitude of $11^{\circ} 36^{\prime} \mathrm{N}$ and $37^{\circ} 10^{\prime} \mathrm{E}$ respectively. It has an elevation of 1840 meters above sea level. There were around 256,999 peoples lived in the city.

Bahir Dar is one of the leading tourist destinations in Ethiopia, with a variety of attractions in the nearby Lake Tana and Blue Nile River. It is now holding an ever increasing number of in flowing domestic and international tourists almost throughout the year. This is due to the presence of natural, historical and cultural attraction sites in and around the city. Hence, Bahir Dar is a frequently visiting place for both heritage and eco tourism. There are hotels and swimming pools in the city. Swimming pools provide as recreational services for the communities of the city as well as visitors. All swimming pools are made of concrete and had different size, shape and depth. They were filled with water from different sources such as fresh ground water, drinking municipal water and running water (from Abay River).

\section{Study design}

A cross-sectional study design was conducted to assess the bacteriological and physico-chemical quality of swimming pools in Bahir Dar from December 2012 to February 2013. All swimming pools are located in Bahir Dar city. All the swimming pools are operating throughout the year. Spread plate and most probable number techniques were used to count aerobic microbes and coliforms from swimming pools respectively. 


\section{Sample size and sample collection}

For sample collection, three swimming pools were used. They were designated as SP1, SP2 and SP3. A total of 81 water samples from three swimming pools (27 water samples from each swimming pool) were collected. The water samples were collected after consultation (about pool water treatment, peak time, source of water and depth of pool water) with each swimming pool authority. The water samples were taken at peak times (4:30 to $5: 30 \mathrm{pm}$ ) when the largest number of swimmers present at the swimming pool in order to increase the probability of getting more microbes in water. They were also taken from the most overcrowded points of the swimming pool where the density of swimmers per unit area was more than other parts of the swimming pool.

Sterile bottles with a volume of $200 \mathrm{~mL}$ were used for collecting water samples from swimming pools. Sodium thiosulphate solutions were added to collected water samples to neutralize residual chlorine. The collected water samples were transported to Bahr Dar University for microbiologicaland physicochemical analysis by keeping the samples in ice box. The samples were processed immediately after arrival within 1-6h from sample collection time to avoid the death and over growth of microbes.

\section{Microbiological analyses}

\section{Total coliform counts}

Total coliforms were counted by following presumptive and confirmatory tests. Lauryl Tryptose Broth was used as presumptive phase to count total coliforms. Lauryl Tryptose Broth (Blulux Laboratories Ltd, India) was prepared and sterilized according to the manufacturer's instruction. From sterile Lauryl Tryptose Broth, $8 \mathrm{ml}$ was transferred into sterile 15 test tubes. By using sterile distilled water, three serial dilution $\left(10^{-1}, 10^{-2}\right.$ and $\left.100^{-3}\right)$ of the pool water samples were prepared. From $10^{-}$ ${ }^{1}$ dilution, $1 \mathrm{~mL}$ was transferred into 5 test tubes. From $10^{-2}$ dilution, $1 \mathrm{~mL}$ was transferred into another 5 tubes. From $10^{-3}$ dilution, $1 \mathrm{~mL}$ was transferred into again another 5 test tubes. In each test tube, sterile durham tube was added. The test tubes were rotated by using vortex to mix the sample with the broth and moved up-down to fill durham tube with broth. The test tubes were incubated at $37^{\circ} \mathrm{C}$ for 48 hours. After incubation period, the number of positive presumptive test tubes (the broth is cloudy and durham tubes contain gas bubbles) were used for farther confirmatory test (APHA, 1995).
Brilliant Green Bile Lactose Broth (Oxoid, England) was used to confirm the presence of total coliforms. Positive presumptive test tubes for total coliforms were rotated in order to re-suspend. From re-suspended positive presumptive test tubes, one loopful culture was inoculated into sterile $8 \mathrm{ml}$ of Brilliant Green Bile Lactose Broth. In each test tube, durham tube was added and filled with broth by moving the test tube up-down.

Then, the test tubes were incubated at $37{ }^{\circ} \mathrm{C}$ for 48 hours. After incubation period, positive test tubes were identified by observing the presence of trapped gas in Durham tubes. The numbers of positive test tubes were read from MPN table and total coliform counts were reported as MPN/ml (APHA, 1995).

\section{Faecal coliform counts}

MacConkey Broth was used as presumptive phase to count faecal coliform. MacConkey Broth (Blulux Laboratories Ltd, India) was prepared and sterilized according to the manufacturer's instruction. From sterile MacConkey Broth, $8 \mathrm{ml}$ was transferred into sterile 15 test tubes. By using sterile distilled water, three serial dilutions $\left(10^{-1}, 10^{-2}\right.$ and $\left.10^{-3}\right)$ of the water samples were prepared. From $10^{-1}$ dilution, $1 \mathrm{~mL}$ was transferred into 5 test tubes.

From $10^{-2}$ dilution, $1 \mathrm{~mL}$ was transferred into another 5 tubes. From $10^{-3}$ dilution, $1 \mathrm{~mL}$ was transferred into another 5 test tubes. All the test tubes were rotated to mix the sample with the broth. After mixing, one Durham tube was added in each test tube and then the durham tube was filed with broth. The test tubes were incubated at $44.5{ }^{0} \mathrm{C}$ for 48 hours. After incubation period, the number of positive presumptive test tubes (the broth is cloudy and durham tubes contain gas bubbles) were used for farther confirmatory test for faecal coliform count (APHA, 1995).

ECBroth (Oxoid, England) was used to confirm the presence of faecal coliforms. Positive presumptive test tubes of faecal coliforms were rotated in order to resuspend. From re-suspended positive presumptive test tube, one loopful culture was inoculated into sterile $8 \mathrm{ml}$ of EC Broth containing Durham tube. Test tubes were rotated and moved up-down. Then, the test tubes were incubated at $44.5{ }^{0} \mathrm{C}$ for 48 hours. After incubation period, positive test tubes were identified by observing the presence of trapped gas in durham tubes. Positive test tubes were read from MPN table and faecal coliform counts were reported as MPN/ml (APHA, 1995). 


\section{Heterotrophic plate counts}

Heterotrophic Plate Count (HPC) was carried out by estimating the number of viable heterotrophic bacteria by inoculating pool water samples on Plate Count Agar (Oxoid, England) through spread plate technique. By using distilled water, pool water samples were diluted serially into $10^{-1}, 10^{-2}, 10^{-3}$ and $10^{-4}$ dilution. From $10^{-4}$ dilution, $0.1 \mathrm{ml}$ suspension was added on the surface of pre-dried plate count agar plates and then it was spread evenly using sterile glass rod. The plates were incubated in inverted position at $37{ }^{\circ} \mathrm{C}$ for 24 hours. After the incubation period, number of colonies were counted and reported as cfu/ml (APHA, 1995).

\section{Physicochemical analyses}

The physicochemical parameters swimming pool water like turbidity, $\mathrm{pH}$, temperature and residual chlorine were measured by following the standard procedure of APHA (1995) and Armand and Cory (2012).

\section{Data analysis}

The results of bacteriological and physicochemical parameter measurements of swimming pools were recorded on the recording forms, and then the data were analyzed using the software SPSS version 16 for windows. The counts of microbiological and physicochemical quality of swimming pool water were compared with World Health Organization (WHO, 2006) guideline. One way Anova was used to check whether, there was statistical significance difference or not among swimming pool quality. The level of significance was set at $5 \%$.

\section{Results and Discussion}

In the present study, a total of 81 pool water samples were collected from three swimming pools (SP1, SP2 and SP3). Bacteriological and physico-chemical parameters of pool water were measured and compared with WHO standard (WHO, 2006).

\section{Bacteriological quality of swimming pools}

\section{Total coliform counts (TCCs)}

The mean total coliform counts were varied from swimming pool to swimming pool. The highest mean of TCC was observed at SP3 swimming pool, 179.63 $\mathrm{MPN} / \mathrm{ml}$ while the lowest TCC mean was observed at
SP1 swimming pool, $120.41 \mathrm{MPN} / \mathrm{ml}$. From total of 81 pool water samples tested for total coliform count from three swimming pools, $62(77 \%)$ was above the limit value of WHO standard whereas only $19(23 \%)$ of the pool water samples was in accordance with the limit value of WHO standard (Table 1).

\section{Faecal coliform counts (TCCs)}

The meanfaecal coliform counts were varied across the three swimming pools. The mean total coliform counts of SP3 swimming pool, SP2 swimming pool and SP1 swimming pool were $89.81,79.37$ and $55.22 \mathrm{MPN} / \mathrm{ml}$ respectively.

From total of 81 pool water samples tested for faecal coliforms from three swimming pools, $55(68 \%)$ was unacceptable by WHO standard while $26(32 \%)$ of the samples was acceptable by WHO standard (Table 2).

\section{Heterotrophic plate counts (HPCs)}

The three swimming pools were showed different mean heterotrophic plate counts. Highest HPC mean was observed at SP3 swimming pool, $222.00 \mathrm{cfu} / \mathrm{ml}$. Lowest mean of HPC was observed at SP1swimming pool, $207.48 \mathrm{cfu} / \mathrm{ml}$. Among 81 pool water samples collected from three swimming pools tested for heterotrophic plate counts, $59(73 \%)$ was above the upper limit of WHO guideline value for HPC $>200 \mathrm{cfu} / \mathrm{ml}$ but $22(27 \%)$ was in line with WHO guideline value for HPC $<200 \mathrm{cfu} / \mathrm{ml}$ (Table 3).

\section{Over all bacteriological compliance of swimming} pools

Lowest numbers of swimming pool samples were full filled WHO standard bacteriological limit. Only $28 \%$ of swimming pool samples were acceptable, below the upper limit value of WHO standard but $72 \%$ of swimming pool samples were unacceptable, above the upper limit value of WHO standard (Table 4).

\section{Comparison of bacteriological quality of swimming pools}

The mean bacteriological counts of pool water samples were compared across the three swimming pools by using one-way Anova. The result of one way nova showed that there was no statistically significant differences among the mean counts of TCC, FCC and HPC $(p=0.05)$ of three swimming pools (Table 5). 


\section{Physico-chemical quality of swimming pools}

\section{Mean value of physico-chemical parameters of swimming pools}

Temperature, $\mathrm{pH}$, turbidity and residual chlorine of swimming pools were measured and recorded. The highest mean temperature was recorded atSP1 swimming pool, $20.78^{\circ} \mathrm{C}$ whereas the lowest temperature was recorded at SP3 swimming pool, $19.00^{\circ} \mathrm{C}$. The highest $\mathrm{pH}$ was observed at SP1 swimming pool, 8.74 while the lowest $\mathrm{pH}$ was observed at SP2 swimming pool, 7.95. The highest turbidity was observed at SP2 swimming pool, 11.48 NTU whereas the least was observed at SP3 swimming pool, 6.99 NTU. In all pool water samples, residual chlorine concentration was less than $1 \mathrm{mg} / \mathrm{l}$. But, the maximum mean residual chlorine was observed at SP2 pool water, 0.019 whereas the minimum mean value was observed at SP3 pool water, 0.002 (Table 6).

\section{Comparison of physico-chemical parameters among swimming pools}

The mean physico-chemical parameter measurements of three swimming pools were compared by using one-way Anova. The result of one-way anova showed that there was statically significant differences in the mean physicochemical parameter measurements $(p=0.05)$ among the three swimming pools (Table 7).

\section{Physico-chemical compliance of swimming pools}

From total of 81 pool water samples tested for turbidity from three swimming pools, 64 (79\%) had greater than 5 Nephelometric Turbidity Unit (5 NTU) and the remaining $17(21 \%)$ of the pool water was ranged between 1-5 NTU. Similarly, 61 (75\%) of pool water $\mathrm{pH}$ was above the upper limit value of WHO standard and $20(25 \%)$ was in line with the limit value of WHO standard. All residual chlorine concentrations of swimming pools were un-acceptable by WHO standard (Table 8).

\section{Correlation between bacteriological and physico- chemical parameters of pool water}

The bacteriological and physico-chemical parameter measurements of SP3 swimming pool was significantly correlated with each other. $\mathrm{pH}$ and turbidity, $\mathrm{pH}$ and HPC, turbidity and HPC were positively correlated with the values of $0.669,0.599$ and 0.436 respectively. On the other hand, chlorine and turbidity, chlorine and HPC were negatively correlated with the values of -0.473 and -0.382 respectively. Correlation also observed between HPC and TC was value 0.867 and between HPC and FC with the value of 0.628 (Table 9).

In present study, coliforms and aerobic microbes were found in all pool water samples. Their prevalence was different among swimming pools. The differences might be variation in source of water and pool water treatment. The occurrence of coliforms and aerobic microbes in pool water may be attributing by poor hygienic practice of swimmers, source of water and poor pool water treatment. The presence of coliforms especially FC in swimming pools indicates evidence of faecal contamination because FC is exclusively faecal in origin. Observation of high counts of HPC indicates ineffectiveness of pool water treatment. Hence high level of HPC resulted due to the availability of nutrients and lack of sufficient level of free residual disinfectant in pool water.

Mavridou et al., (2001) and Oloruntoba et al., (2007) reported that total coliforms were found in all pool water samples. Rodriguez (2008) reported that $32 \%$ of swimming pool water samples were contaminated with total coliforms. Jabu et al., (2005) showed that pool water samples were not contaminated with total coliforms because pool water was treated properly.

Rabi et al., (2007) reported that $94.7 \%$ of swimming pool samples were contaminated with FC. Another study done by Itah and Ekpombok (2004) reported that all of the water samples of the swimming pools were positive for FC. Martins et al., (1995) showed that FC was not found in all pool water samples but $5.6 \%$ of the swimming pools contained FC.

Maida (2008) reported that none of the faecal coliforms were found in pool water. Nabizadeh et al., (2008) isolated TC, FC and HPC from swimming pools.

Majority of swimming pool water samples were not fulfilled the recommended WHO standard bacteriological limits. From total of 81 pool water samples, $77 \%$ was above WHO standard limit of total coliform (Table 1). This result was greater than the finding of Sule (2010) who reported that $66.7 \%$ pool water samples was above WHO standard limit of total coliform. But the current study result was opposed to the finding of Oloruntoba (2007) who reported that all total coliform counts of pool water samples were below the upper limit of WHO standard. 
Table.1 Mean total coliform counts and compliance of swimming pools

\begin{tabular}{|c|c|c|c|c|}
\hline $\begin{array}{c}\text { Swimming } \\
\text { Pools }\end{array}$ & $\begin{array}{c}\text { Total No. of } \\
\text { samples }\end{array}$ & Mean and Sd & $\begin{array}{c}\text { WHO acceptable limit } \\
(<1 \mathrm{MPN} / \mathrm{ml})\end{array}$ & $\begin{array}{c}\text { WHO un-acceptable } \\
\text { limit (> 1MPN/ml })\end{array}$ \\
\hline SP1 & 27 & $120.41 \pm 85.18$ & $8(30 \%)$ & $19(70 \%)$ \\
\hline SP2 & 27 & $149.48 \pm 84.08$ & $7(26 \%)$ & $20(74 \%)$ \\
\hline SP3 & 27 & $179.63 \pm 155.99$ & $4(15 \%)$ & $23(85 \%)$ \\
\hline Total & 81 & --- & $19(23 \%)$ & $62(77 \%)$ \\
\hline
\end{tabular}

Table.2 Mean faecal coliform counts and compliance of swimming pools

\begin{tabular}{|l|c|l|l|l|}
\hline $\begin{array}{l}\text { Swimming } \\
\text { Pools }\end{array}$ & $\begin{array}{l}\text { Total No. of } \\
\text { samples }\end{array}$ & Mean and Sd & $\begin{array}{l}\text { WHO acceptable } \\
\text { limit }(<1 \mathrm{MPN} / \mathrm{ml})\end{array}$ & $\begin{array}{l}\text { WHO un-acceptable } \\
\text { limit }(>1 \mathrm{MPN} / \mathrm{ml})\end{array}$ \\
\hline SP1 & 27 & $55.22 \pm 40.86$ & $11(41 \%)$ & $16(59 \%)$ \\
\hline SP2 & 27 & $79.37 \pm 49.57$ & $10(37 \%)$ & $17(63 \%)$ \\
\hline SP3 & 27 & $89.81 \pm 59.68$ & $5(19 \%)$ & $22(81 \%)$ \\
\hline Total & 81 & --- & $26(32 \%)$ & $55(68 \%)$ \\
\hline
\end{tabular}

Table.3 Mean and compliance of heterotrophic plate counts from swimming pools

\begin{tabular}{|l|l|l|c|c|}
\hline $\begin{array}{l}\text { Swimming } \\
\text { Pools }\end{array}$ & $\begin{array}{l}\text { Total No. of } \\
\text { samples }\end{array}$ & Mean and Sd & $\begin{array}{l}\text { WHO acceptable } \\
(\text { HPC <200 cfu/ml })\end{array}$ & $\begin{array}{l}\text { WHO un-acceptable } \\
(\text { HPC >200 cfu/ml })\end{array}$ \\
\hline SP1 & 27 & $207.48 \pm 47.30$ & $10(37 \%)$ & $17(63 \%)$ \\
\hline SP2 & 27 & $208.22 \pm 94.04$ & $8(30 \%)$ & $19(70 \%)$ \\
\hline SP3 & 27 & $222.00 \pm 67.34$ & $4(15 \%)$ & $23(85 \%)$ \\
\hline Total & 81 & --- & $22(27 \%)$ & $59(73 \%)$ \\
\hline
\end{tabular}

Table.4 Over all bacteriological compliance of swimming pools

\begin{tabular}{|l|l|l|l|}
\hline $\begin{array}{l}\text { Bacteriological } \\
\text { parameters }\end{array}$ & $\begin{array}{l}\text { Total No. of } \\
\text { samples }\end{array}$ & $\begin{array}{l}\text { WHO acceptable } \\
(<1 \mathrm{MPN} / \mathrm{ml} \text { for FC and TC) } \\
(<200 \mathrm{cfu} / \mathrm{ml} \text { for HPC })\end{array}$ & $\begin{array}{l}\text { WHO un-acceptable } \\
(>1 \mathrm{MPN} / \mathrm{ml} \text { for FC and TC) } \\
(>200 \mathrm{cfu} / \mathrm{ml} \text { for HPC })\end{array}$ \\
\hline FC & 81 & $26(32 \%)$ & $55(68 \%)$ \\
\hline TC & 81 & $19(23 \%)$ & $62(77 \%)$ \\
\hline HPC & 81 & $22(27 \%)$ & $59(73 \%)$ \\
\hline Total & 243 & $67(28 \%)$ & $176(72 \%)$ \\
\hline
\end{tabular}

Table.5 Analysis of variance table for TCC, FCC and HPC of swimming pools

\begin{tabular}{|l|l|l|l|l|}
\hline \multirow{2}{*}{$\begin{array}{l}\text { Bacteriological } \\
\text { parameters }\end{array}$} & \multicolumn{3}{|c|}{ Swimming pools } & \multirow{2}{*}{ P value } \\
\cline { 2 - 4 } & SP1 & SP2 & SP3 & \\
\hline FCC & $55.22 \pm 40.86$ & $79.37 \pm 49.57$ & $89.81 \pm 59.68$ & 0.109 \\
\hline TCC & $120.41 \pm 85.18$ & $149.48 \pm 84.08$ & $179.63 \pm 155.99$ & 0.166 \\
\hline HPC & $207.48 \pm 47.30$ & $208.22 \pm 94.04$ & $222.00 \pm 67.34$ & 0.708 \\
\hline
\end{tabular}


Table.6 Mean value of physicochemical parameters of swimming pools

\begin{tabular}{|l|l|l|l|}
\hline \multirow{2}{*}{$\begin{array}{l}\text { Physico-chemical } \\
\text { parameters }\end{array}$} & \multicolumn{3}{|c|}{ Swimming pools } \\
\cline { 2 - 4 } Temperature $\left.{ }^{0} \mathrm{C}\right)$ & $20.78 \pm 1.53$ & SP2 & SP3 \\
\hline $\mathrm{pH}$ & $8.74 \pm 0.19$ & $7.95 \pm 0.36$ & $19.00 \pm 1.04$ \\
\hline Turbidity (NTU) & $8.59 \pm 3.76$ & $11.48 \pm 6.35$ & $6.44 \pm 0.30$ \\
\hline Residual chlorine & $0.010 \pm 0.002$ & $0.019 \pm 0.004$ & $0.002 \pm 0.001$ \\
\hline
\end{tabular}

Table.7 Analysis of variance table for physico-chemical measurements of swimming pools

\begin{tabular}{|l|l|l|l|l|}
\hline \multirow{2}{*}{$\begin{array}{l}\text { Physico-chemical } \\
\text { parameters }\end{array}$} & \multicolumn{3}{|c|}{ Swimming pools } & P value \\
\cline { 2 - 5 } & SP1 & SP2 & SP3 & \\
\hline $\mathrm{T}^{0} \mathrm{C}$ & $20.78 \pm 1.53^{\mathrm{a}}$ & $19.56 \pm 1.28^{\mathrm{b}}$ & $19.00 \pm 1.04^{\mathrm{b}}$ & $<0.001$ \\
\hline $\mathrm{pH}$ & $8.74 \pm 0.19^{\mathrm{a}}$ & $7.95 \pm 0.36^{\mathrm{b}}$ & $8.44 \pm 0.30^{\mathrm{c}}$ & $<0.001$ \\
\hline Turbidity & $8.59 \pm 3.76^{\mathrm{a}}$ & $11.48 \pm 6.35^{\mathrm{b}}$ & $6.99 \pm 2.53^{\mathrm{a}}$ & 0.002 \\
\hline Residual chlorine & $0.010 \pm 0.002^{\mathrm{a}}$ & $0.019 \pm 0.004^{\mathrm{a}}$ & $0.002 \pm 0.001^{\mathrm{b}}$ & 0.042 \\
\hline
\end{tabular}

Legend: $a, b$, and $\mathrm{c}$ indicates statistically significance difference of the recorded values of swimming pool parameter measurements.

Table.8 Compliance level of physicochemical parameters of swimming pools ( $\mathrm{n}=81$ )

\begin{tabular}{|c|c|c|c|c|c|c|c|c|c|}
\hline \multirow{3}{*}{$\begin{array}{l}\text { Physico- } \\
\text { chemical } \\
\text { parameters }\end{array}$} & \multirow{3}{*}{$\begin{array}{l}\text { Limit } \\
\text { value of } \\
\text { WHO }\end{array}$} & \multicolumn{6}{|c|}{ Swimming pools } & \multicolumn{2}{|c|}{ Total } \\
\hline & & \multicolumn{2}{|c|}{ SP1 } & \multicolumn{2}{|c|}{ SP2 } & \multicolumn{2}{|c|}{ SP3 } & \multirow{2}{*}{$\begin{array}{l}\text { No. of } \\
\text { samples }\end{array}$} & \multirow{2}{*}{$\begin{array}{l}\text { Percent } \\
(\%)\end{array}$} \\
\hline & & $\begin{array}{l}\text { No. of } \\
\text { samples }\end{array}$ & $\begin{array}{l}\text { Percent } \\
(\%)\end{array}$ & $\begin{array}{l}\text { No. of } \\
\text { samples }\end{array}$ & $\begin{array}{l}\text { Percent } \\
(\%)\end{array}$ & $\begin{array}{l}\text { No. of } \\
\text { samples }\end{array}$ & $\begin{array}{l}\text { Percent } \\
(\%)\end{array}$ & & \\
\hline \multirow{3}{*}{$\begin{array}{l}\text { Residual } \\
\text { chlorine } \\
(\mathrm{mg} / \mathrm{l})\end{array}$} & $>3$ & 0 & 0 & 0 & 0 & 0 & 0 & 0 & 0 \\
\hline & $1-3$ & 0 & 0 & 0 & 0 & 0 & 0 & 0 & 0 \\
\hline & $<1$ & 81 & 100 & 81 & 100 & 81 & 100 & 81 & 10 \\
\hline \multirow{3}{*}{$\begin{array}{l}\text { Turbidity } \\
\text { (NTU) }\end{array}$} & $>5$ & 20 & 25 & 23 & 28 & 21 & 26 & 64 & 79 \\
\hline & $1-5$ & 4 & 5 & 7 & 9 & 6 & 7 & 17 & 21 \\
\hline & $<1$ & 0 & 0 & 0 & 0 & 0 & 0 & 0 & 0 \\
\hline \multirow{3}{*}{$\mathrm{pH}$} & $>7.9$ & 22 & 27 & 19 & 23 & 20 & 25 & 61 & 75 \\
\hline & $7.2-7.8$ & 8 & 10 & 5 & 6 & 7 & 9 & 20 & 25 \\
\hline & $<7.1$ & 0 & 0 & 0 & 0 & 0 & 0 & 0 & 0 \\
\hline \multirow{3}{*}{$\begin{array}{l}\text { Temperatur } \\
\mathrm{e} \\
\left({ }^{0} \mathrm{C}\right)\end{array}$} & $>32$ & 0 & 0 & 0 & 0 & 0 & 0 & 0 & 0 \\
\hline & $21-32$ & 8 & & 6 & & 4 & & 18 & 22 \\
\hline & $<20$ & 19 & & 23 & & 21 & & 63 & 78 \\
\hline
\end{tabular}


Table.9 Correlation of physico-chemical and bacteriological measurements of SP3 swimming pool

\begin{tabular}{|l|l|l|l|l|l|l|l|l|}
\hline & & Tem & $\mathrm{pH}$ & $\mathrm{CL}_{2}$ & Turbidity & HPC & TC & FC \\
\hline \multirow{3}{*}{ Tem } & Corr & - & -0.282 & 0.449 & -0.071 & -0.122 & -0.397 & -0.065 \\
\cline { 2 - 9 } & Sig & - & 0.155 & $0.019^{*}$ & 0.726 & 0.544 & $0.040^{*}$ & 0.747 \\
\hline \multirow{2}{*}{$\mathrm{pH}$} & Corr & -0.282 & - & -0.578 & 0.669 & 0.599 & 0.298 & 0.589 \\
\cline { 2 - 9 } & Sig & 0.155 & - & $0.002^{*}$ & $0.00^{*}$ & $0.00^{*}$ & 0.132 & $0.001^{*}$ \\
\hline \multirow{2}{*}{$\mathrm{CL}_{2}$} & Corr & 0.449 & -0.578 & - & $-0,473$ & -0.382 & -0.272 & -0.291 \\
\cline { 2 - 9 } & Sig & $0.019^{*}$ & $0.002^{*}$ & - & $0.013^{*}$ & $0.049^{*}$ & 0.196 & 0.141 \\
\hline \multirow{3}{*}{ Turbidity } & Corr & -0.071 & 0.669 & -0.473 & - & 0.436 & 0.408 & 0.280 \\
\cline { 2 - 9 } & Sig & 0.726 & $0.00^{*}$ & $0.013^{*}$ & - & $0.023^{*}$ & $0.035^{*}$ & 0.157 \\
\hline \multirow{2}{*}{ HPC } & Corr & -0.122 & 0.559 & -0.382 & 0.436 & - & 0.867 & 0.628 \\
\cline { 2 - 9 } & Sig & 0.544 & $0.002^{*}$ & $0.049^{*}$ & $0.023^{*}$ & - & $0.00^{*}$ & $0.00^{*}$ \\
\hline \multirow{3}{*}{ TC } & Corr & -0.397 & 0.298 & -0.272 & 0.408 & 0.867 & - & 0.499 \\
\cline { 2 - 9 } & Sig & $0.040^{*}$ & 0.132 & 0.169 & $0.035^{*}$ & $0.00^{*}$ & - & $0.004^{*}$ \\
\hline \multirow{2}{*}{ FC } & Corr & -0.065 & 0.589 & -0.291 & 0.280 & 0.628 & 0.499 & - \\
\cline { 2 - 9 } & Sig & 0.747 & $0.001^{*}$ & 0.141 & 0.157 & $0.00^{*}$ & $0.004^{*}$ & - \\
\hline
\end{tabular}

Key: Tem=temperature, HPC=heterotrophic plate count, $\mathrm{TC}=$ total coliform, $\mathrm{FC}=$ fecal coliform, Corr=correlation, Sig=significance, $*=$ indicates correlation.

Among pool water samples, 68\% was above the recommended level of WHO standard limit of faecal coliform (Table 2). The finding done by Rabi et al., (2007who reported that $57 \%$ of pool water samples was above WHO standard. Cappello (2011) reported that all swimming pool samples were fulfilled WHO standard of faecal coliform limit.

The compliance level of HPC was ranged from $63 \%$ to $85 \%$ (Table 3). Low level of compliance was observed from water samples collected from SP1 swimming pool. This is due to observation of low bather load and utilization of filtration technique. On the other hand, high level of compliance was observed at SP3 swimming pool (Table 3). The reasons might be the presence of higher bather load and use less residual chlorine concentration when compare with other swimming pools. A study done by Martins et al., (1995) and Barrel et al., (2000) reported that heterotrophic plate counts of pool water were related positively with swimmer densities.

Over all $72 \%$ of pool water samples did not confirm to the recommended WHO standard bacteriological limit (Table 4). Surveys reported from different countries were showed different results of bacteriological quality of swimming pools. In South Australia, 18\% of the pool water samples was unacceptable (Esterman et al., 1984). In Athens 2004 Olympic, microbiological quality of 374 swimming pools were examined in different months and observed different results. Pool water samples collected from January -May 2004 year, 10\% was reported as unsatisfactory. A pool water sample collected from MayJuly 2004 year, 5\% was un-acceptable (Hadjichristodoulou et al., 2004). In Ambo and DebreZeit, Addis Ababa, 67\% pool water samples did not conform to the recommended WHO standard (ThewodrosBekele, 2008). In North West Greece, 32.9\% did not conform to the recommended bacteriological limits (Papadopoulou et al., 2011). A study done in Egypt, $56.7 \%$ of the pool water samples were found microbiologically unacceptable (Abd El-Salam, 2012).

All of pool water samples $(100 \%)$ had residual chlorine concentration less than WHO standard limit (Table 7).The reasons for such low level of residual chlorine might be expensive the cost of chlorine, poor knowledge of pool operator and the presence of high level of organic matter. Nanbakhsh et al., (2004) found that the residual chlorine concentration of all swimming pool samples was lower than the recommended WHO standard. Bilajac et al., (2012) reported that $82.8 \%$ of pool water confirms to the recommended WHO standard for residual chlorine concentration limit.

From total of 81 pool water samples, $79 \%$ was above the recommended WHO guideline level (>5FNU) (Table 8). Such result was in agreement with the finding of Rabi et al., (2007) who reported that $71 \%$ of pool water samples was above WHO standard but disagree with the finding of Dindarlou (2003) who reported that turbidity measurement in all of samples was less than 1 NTU. The sources of the observed turbidity may include presence 
of organic or inorganic suspended materials from working place, soil, dust and pollen, microorganisms from swimmers, use of unfiltered running water and poor application of disinfectants. High turbidity can interfere with disinfection and provide a medium for microbial growth. Hence, for effective disinfection the turbidity should be below 1 NTU. In this study, none of the swimming pools fulfilled the recommended limit set by WHO (2006).

Only $25 \%$ of the water samples from three swimming pools had $\mathrm{pH}$ within the range of 7.2-7.8 as recommended by WHO (2006). But $75 \%$ did not conform to the recommended WHO limits. Mehdi (2003) and (Magda, 2012) reported that $80 \%$ and $47 \%$ of pool water samples did not conform to the recommended WHO standard respectively. Sule (2010) reported that the $\mathrm{pH}$ of pool water samples was ranged within 6.4-7.6 $\mathrm{pH}$.

In analysis of the physicochemical quality of pool water samples for temperature, $78 \%$ was less than the recommended limit of WHO standard. Only 22\% of samples were found to be met the WHO standard acceptable limit (table 8). Report from study conducted in AkwaIbon State, Nigeria reported that the temperature measurement of all pool water samples were in line with WHO standards (Itah, and Ekpombok, 2004).

A study conducted in Kashan, Iran, indicated that conformity of the swimming pool water to the standards was $71 \%$ for residual chlorine, $88 \%$ for $\mathrm{pH}, 63 \%$ for turbidity and $10 \%$ for water temperature (Rasti et al., 2012). Findings of the current study indicate that the $\mathrm{pH}$ of swimming pool water was a better quality in comparison with Iran, but the parameter of turbidity was higher in this study, in comparison with Iran. The residual chlorine of swimming pool water in Kashan Iran was better quality in comparison with the present study.

Generally, the observed weak controlling system of the related parameters $(\mathrm{pH}$, chlorine, turbidity) of swimming pools may contribute more prevalence of pathogens in pool water. High turbidity and less available chlorine were observed in most of the swimming pools samples may contribute a lot for the presence of pathogens. During swimming, the consumption of highly turbid water may constitute a health risk as excessive turbidity can protect pathogenic microorganisms from the effects of disinfectants, and also stimulate the growth of bacteria (Chan et al., 2007). Majority of pool water samples are not acceptable by WHO standard bacteriological limits
(TCC and FCC). The presences of high significant coliform counts indicate the contamination of the pool water with enteric pathogens. So, using these pools may cause SPWIs like typhoid fever, shigellosis, cholera and diarrhea (Itah and Ekpombok, 2004).

The bacteriological results from this study showed that most of the bacteriological parameters measured (TC, FC and HPC) were not confirm with the recommended limits set out by WHO standard and most of the swimming pools investigated were grossly polluted. Similarly, the physicochemical parameters (residual chlorine, turbidity, $\mathrm{pH}$ and temperature) measured from swimming pools were not in accordance with WHO limit values. So, the result indicates poor disinfection or poor hygiene practice of swimmers. This situation could result in health hazards for the swimmers and the surrounding communities due to the spread of microorganisms. Therefore, call for more strict surveillance measures from responsible health authorities for protection of swimmers' health. Pool water must meet and constantly checked for quality criteria including bacteriological and physicochemical standards at appropriate intervals. Strict legislation with the aim of insuring the safety of pool is highly required.

\section{References}

Abd El-Salam, MM. (2012). Assessment of water quality of some swimming pools: a case study in Alexandria, Egypt. Environmental monitoring and assessment, 184: 1573-2959.

APHA (1995).Standard methods for the examination of water and waste water, 19th edition Washington DC.

Armand, R. and Cory, L. (2012). Standard operating procedures for manual field measurement of turbidity. California Department of Transportation Division of Environmental Analysis.

Barrell, R., Hunter, PR. and Gichols, G. (2000). Microbiological standards for water and their relationship to health risk. Community Disease Public Health, 3: 8-13.

Bello OO, Mabekoje OO, Egberongbe $\mathrm{HO}$ and Bello TK (2012). Microbial qualities of Swimming Pools in Lagos, Nigeria. International Journal of Applied Science and Technology, 2: 89-96.

Bilajac, L., Vukić, L. D., Doko, J. J. and Rukavina, T. (2012). Microbiological and chemical indicators of water quality in indoor hotel swimming pools before and after training of swimming pool operators. Journal of Water Health10:108-115. 
Cappello, A. M. (2011). Assessing Bacteriological Contamination in Public Swimming Facilities within a Colorado Metropolitan Community. Journal of Environmental Health, 73:19-25.

Castor, M. L. (2004). Safe swimming. Talk to parents about preventing recreational water illnesses. American Academy of Pediatrics Newsletter pp. 226-227.

CDC (2008). Violations identified from routine swimming pool inspections - Selected states and countries, United States. Morbidity and Mortality Weekly Report, 59:582-587.

Centre for Disease Control (2001). Shigellosis outbreak associated with an unchlorinated fill and- drain wading pool - Iowa, 2001. Morbidity and Mortality Weekly Report, 50: 797-800

Chan, C., Zalifah, M. K. and Norrakiah, A. S. (2007). Microbiological and physicochemical quality of drinking water. The Malaysian Journal of Analytical Science 1(2): 417-419.

Chase, N.L., Sui X. and Blair S. (2008). Swimming and all-cause mortality risk compared with running, walking, and sedentary habits in men. International Journal of Aquatic Research and Education, 2:21323.

Dindarlou, K., Soleymani A. M., Zare S. M., Abdi H. and Heydari M. (2003). Hygiene condition of Bandar Abbas swimming pools. Medical Journal of Hormozgan University, 9:41-46.

Esterman, A., Roder, D. M., Scott C. A., Robinson B. S., Walters R. P., Lake, J. A. and Christy, P. E. (1984). Determinants of the microbiological characteristics of South Australian swimming pools. Applied Environmental Microbiology, 47:325-328.

Hadjichrisrodoulu, C., Mouchtouri V., Vousoureli A., Konstantinidis A., Petrikos P., Velonakis E., Boufa P. and Kremastinou, S. (2004). Waterborne disease prevention: Evaluation of inspection scoring system for water sites according to water microbiological test during the Athens 2004 Pre-olympic and Olympic Period. Journal Epidemiological Community Health, 60: 829-835.

Itah, Y. A. and Ekpombok M. U. (2004). Pollution status of swimming pools in South-South Zone of SouthEastern Nigeria using microbiological and physicochemical indices. Indices of swimming pools contamination in Nigeria, 35: 488-493.

Jabu, G. C. and Grimason, A. M. (2005).Assessment and comparison of microbial quality of drinking water in Chikwawa, Malawi. Department of Civil Engineering, pp. 1-7.
Magda, A. E. (2012). Swimming pools: a case study in Alexandria, Egypt. Environmental monitoring and assessment. Springer Journal, 184: 7395-7406.

Maida, CM, Benedetto MA, Firenze A., Calamusa G., Piazza F., Milici, ME and Romano N. (2008). Surveillance of the sanitary conditions of a public swimming pool in the city of Palermo (Italy). Iglene Sanita Pubblica, 64: 581-93.

Martins, M. T., Sato M. I. Z., Alves M. N., Stoppe N. C., Prado V. M. and Sanchez P. S. (1995). Assessment of microbiological quality for swimming pools in South America. Pergamon, 29: 2417-2420.

Mavridou, A., Vagiona A., Boufa P. and Vantarakis A. (2001). Assessment of the quality of pool water in Greece using various microbial indicators. Department of Environmental Microbiology, pp. 15.

Mehdi, N. M. (2003). The determination of quality of healthy indicators in swimming pools in Gorgan. Gorgan University Journal Medical Science, 5: 8487.

Nabizadeh, R., Samadi N., Sadeghpour Z. and Beikzadeh M. (2008). Feasibility study of using complex of hydrogen peroxide and silver for disinfecting swimming pool water and its environment. Iran Journal Environmental Health Science Engineering, 5: 235-242.

Nanbakhsh, H., Diba K. and Hazarti K. (2004). Study of fungal contamination of indoor public swimming pools. Iran Journal Public Health, 33: 60-65.

Oloruntoba, E. O., Mynepalli K. C. and Sridhar C. T. (2007). Assessment of microbiological quality and sanitary status of swimming pools, in Ibadan, Nigeria. International Water Association, pp. 1-6.

Papadopoulou, C., Economou V. and Sakkas H. (2008, 2011). Microbiological quality of indoor and outdoor swimming pools in Greece: Investigation of the antibiotic resistance of the bacterial isolates. International Journal Hygiene Environmental Health, pp. 385-397.

Rabi, A., Yousef K., Ahmed A. and Ashraf A. (2007). Sanitary conditions of public swimming pools in Amman, Jordan. International Journal Environmental Research Public Health, 4: 301-306.

Rasti, S., Mohammad A., Leila I., Mahmood S., Hamid R. and Mohammad P. (2012). Assessment of microbial contamination and physicochemical condition of public swimming pools in Kashan, Iran. Jundishapur Journal Microbiology, 5: 450455.

Rodriguez-Morales, A. J., Mora C. N. and Meijomil P. (2008). Antimicrobial susceptibility of bacterial 
strains isolated from recreational swimming pools in two provinces of North-Central Venezuela. Comunicación Corta - Short Report, 39: 11-14.

Sule, I. O. (2010). Physicochemical and bacteriological assessment of some swimming pools within Ilorin Metropolis, Kawara, Nigeria. Best Journal, 7: 108112.

Thewodros Bekele (2008). Assessment of bacteriological physicochemical quality of recreational water

How to cite this article:

Melkam Dessalegn and Mulugeta Kibret. 2018. Bacteriological and Physicochemical Quality of Swimming Pools in Bahir Dar, Ethiopia. Int.J.Curr.Res.Aca.Rev. 6(10), 51-61. doi: https://doi.org/10.20546/ijcrar.2018.610.006 bodies case studies from Addis Ababa, Ambo and Debre Zeit. M.Sc. Thesis, Addis Ababa University.

Thomas, G. and Trammel F. (2007). Drowning in disinfection byproducts? Assessing swimming pool water. Critical Reviews in Environmental Science and Technology, 41: 363-372.

WHO (2006). Guidelines for safe recreational Water environments, Vol. 2: Swimming pools and similar environments. WHO, Geneva. 